\title{
Nasal exhaled nitric oxide measurements on British Asian children with confirmed Primary Ciliary Dyskinesia
}

\author{
E Turner ${ }^{*}$, M Balain, EF Moya, P Dawson \\ From First International Cilia in Development and Disease Scientific Conference (2012) \\ London, UK. 16-18 May 2012
}

\section{Introduction}

The prevalence of Primary Ciliary Dyskinesia (PCD) in British Asian children in Bradford is 1 in 2265. This is the highest in the UK and more common than Cystic Fibrosis. 1) The use of Nasal Exhaled Nitric Oxide (ENO) as a screening tool for PCD was a suggested by ATS/ERS recommendations in 2005. 2) We have collected values for British Asian children with PCD in Bradford.

\section{Methods}

26 children in Bradford have a confirmed diagnosis of PCD by Nasal Cilia brushings. 24 children are of British Asian origin. We obtained nasal ENO values for 16 children.

\section{Results}

14/16 children with confirmed PCD had nasal ENO values $<100$.

\section{Summary}

Our results in British Asian children agree with evidence suggesting Nasal ENO may be used as a screening tool for PCD. Next step, The Bradford Exhaled Nitric Oxide (BENO) Study aims to generate normal reference nasal ENO values from healthy School aged British Asian children in Bradford. If values in children with PCD are consistently lower than in healthy children, we hope to introduce nasal ENO as a screening tool for PCD for British Asian Children in Bradford.

Published: 16 November 2012

Bradford Royal Infirmary, UK

\section{References}

1. O'Callaghan C, Chetcuti P, Moya EF: High prevalence of Primary Ciliary Diskinesia in a British Asian Population. Archives of Disease in Childhood 2010, 95:51-52.

2. ATS/ERS recommendations for standardized procedures for the online and offline measurements of exhaled lower respiratory nitric oxide and nasal nitric oxide. American Journal of Respiratory Critical Care Medicine 2005, 171:912-930.

doi:10.1186/2046-2530-1-S1-P9

Cite this article as: Turner et al: Nasal exhaled nitric oxide measurements on British Asian children with confirmed Primary Ciliary Dyskinesia. Cilia 2012 1(Suppl 1):P9.
Submit your next manuscript to BioMed Central and take full advantage of:

- Convenient online submission

- Thorough peer review

- No space constraints or color figure charges

- Immediate publication on acceptance

- Inclusion in PubMed, CAS, Scopus and Google Scholar

- Research which is freely available for redistribution

\section{() Biomed Central}

() Biomed Central

(C) 2012 Turner et al; licensee BioMed Central Ltd. This is an Open Access article distributed under the terms of the Creative Commons Attribution License (http://creativecommons.org/licenses/by/2.0), which permits unrestricted use, distribution, and reproduction in any medium, provided the original work is properly cited. 